Politik Ekonomik Kuram 2019, Cilt 3(2), 177-191

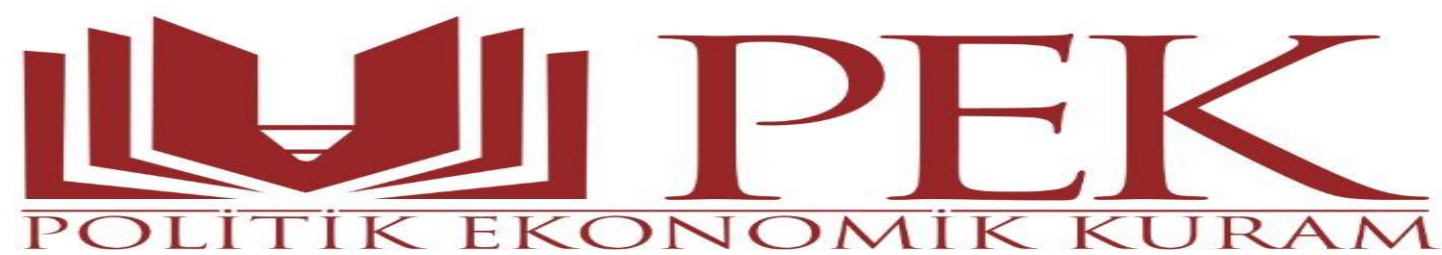

\title{
Kamu Kesimi Açıklarının Finansmanında Maliye Politikasının Rolü
}

Baki YEGEN*

\section{Makale Bilgileri}

Makale Geçmişi:

Makalenin Yüklendiği Tarih: 13.10.2019

Makalenin Kabul Edildiği Tarih: 15.12.2019

Anahtar Kelimeler: Kamu Kesimi, Bütçe, Maliye Politikası.

* Dr. Öğr. Üyesi, Niğde Ömer Halisdemir Üniversitesi, İIBF, Maliye Bölümü, bakiyegen@ohu.edu.tr. 
Yegen, B. (2019), “Kamu Kesimi Açıklarının Finansmanında Maliye Politikasının Rolü”, Politik Ekonomik Kuram, Cilt 3(2)

\title{
Özet
}

Klasik maliye teorisinden modern maliye teorisine geçilmesiyle birlikte devletin ekonomik ve sosyal hayata müdahale etmesi gerektiği yönündeki düşünce benimsenmiştir. Bu düşünce özellikle 1970'li yıllarla birlikte artan kamu harcamalarına bağlı olarak beraberinde kamu kesimi açı̆̆ı olgusunu gündeme getirmiştir. Zamanla kamu kesimi açığı pek çok devlet için sorun olmaya başlamış ve devletler kamu kesimi açıklarını finanse etmek için borçlanma, vergiler ve emisyon yöntemlerini kullanmaya başlamışlardır. Günümüzde devletler kamu kesimi açıklarının finansmanında daha çok borçlanma yöntemini tercih etmektedirler. Ancak borçlanma yöntemi iyi bir borç yönetimiyle olumlu ekonomik sonuçlara neden olabilmektedir. Bu nedenle borçlanma konusunda devletlerin son derece dikkatli davranmaları gerekmektedir. Ayrıca konjonktürel dalgalanma dönemlerinde içinde bulunulan olumsuz ekonomik durumdan kurtulmak için uygulanacak maliye politikasına göre farklı kamu kesimi bütçe anlayışları benimsenmektedir. Şöyle ki durgunluk döneminde uygulanan genişletici maliye politikaları kamu kesiminde bütçe açı̆̆ı anlayışının, enflasyon döneminde uygulanan daraltıcı maliye politikaları ise kamu kesiminde bütçe fazlası anlayışının benimsendiğine işaret etmektedir.

\section{The Role of Fiscal Policy in Financing Public Sector Deficit}

\begin{abstract}
The idea that the government should intervene in economic and social life is adopted with the transition from classical public finance theory to modern public finance theory. This idea has brought on the agenda phenomenon of the public sector deficit especially due to the increasing public expenditures in the 1970s. In time, the public sector deficit has become a problem for many governments and governments have started to use borrowing, taxes and emission methods to finance public sector deficits. Nowadays, governments prefer more borrowing method in financing public sector deficits. However, the borrowing method can lead to positive economic results with a good debt management. For this reason, governments should be very careful about borrowing. In addition, different public sector budget approaches are adopted according to the fiscal policy that will be applied to get rid of the negative economic situation in cyclical fluctuations. Thus, the expansionary fiscal policies implemented during the recession period point to the adoption of the budget deficit in the public sector, the contractionary fiscal policies implemented during the inflation period point to the adoption of the budgetary surplus in the public sector.
\end{abstract}

Key Words: Public Sector, Budget, Fiscal Policy. 
Yegen, B. (2019), “Kamu Kesimi Açıklarının Finansmanında Maliye Politikasının Rolü”, Politik Ekonomik Kuram, Cilt 3(2)

\section{Giriş}

Devletin temel görevlerini yerine getirmesinin yanında ekonomik ve sosyal hayata müdahale etmesi gerektiği yönündeki Keynesyen görüşün önem kazanmasıyla birlikte kamu kesiminin etki alanı genişlemiş ve bu durumun doğal bir sonucu olarak kamu kesimi harcamaları artış göstermiştir. Artan kamu harcamaları ise daha fazla kamu gelirine ihtiyaç duyulmasına neden olmuştur. Ancak kamu kesimi tarafından yapılan harcamaların finansmanı konusunda beklenilen düzeyin altında kamu geliri tahsil edilmesi kamu kesimi açıklarına yol açmıştır. Kamu kesimi açıkları ise günümüz dünyasında halen geçerliliğini korumakla birlikte pek çok ülke açısından ciddi bir sorun olmaktadır. Kamu kesimi finansman açıklarının büyüklükleri ülkeden ülkeye farklılık göstermekle birlikte ülke ekonomisi üzerinde neden oldukları olumsuz durumlardan ötürü kuşkusuz hiçbir ülke tarafından arzu edilmemektedirler. Devletler söz konusu açıkların finansmanları konusunda ise vergilendirme, kamu borçlanması ve emisyon gibi farklı özelliklere sahip çeşitli maliye politikası araçlarına başvurabilmektedirler. Kamu kesimi finansman sorununun ele alındığı bu çalışmada sırasıyla kamu kesimi açığı kavramı ile ilgili genel açıklamalara, kamu açıklarıyla ilgili iktisadi yaklaşımlara, kamu açıklarının finansmanı hususunda tercih edilen maliye politikası araçlarına ve söz konusu araçların iktisadi etkilerine yer verilmektedir.

\section{Kamu Kesimi Açığı Kavramı}

Basit bir şekilde ifade etmek gerekirse bütün kamu kesimine ait giderler ile yine bütün kamu kesimine ait gelirler arasındaki fark kamu kesimi açığını meydana getirmektedir (Pehlivan, 2018a: 45). Buna göre kamu kesimi açıkları merkezi yönetime, yerel yönetimlere, kamu iktisadi teşebbüslerine (KİT) ve sosyal güvenlik kuruluşlarına ait bütçe gerçekleşmeleri ile fonların toplamından oluşmaktadır (Kirmanoğlu, 2011: 41). Ayrıca kamu kesimi açı̆̆ından bahsedebilmek için şüphesiz kamu kesimi tarafından yapılan giderlerin toplanılan gelirlerden daha fazla olmaları gerekmektedir.

Kamu kesimi açıklarının gelişsimi devletin artan fonksiyonlarına bağlı olarak yaşanmıştır. $\mathrm{Bu}$ kapsamda özellikle 1929 yılında yaşanan Büyük Buhran sonrasında Keynesyen görüş etkili olmuştur (Adak, 2010: 234). Keynesyen görüşle birlikte devletin kamu maliyesi ile ilgili faaliyetleri artmış ve devletin fonksiyonlarında meydana gelen gelişmeler doğrultusunda kamu harcamaları da artmıştır. Yaşanan tüm bu gelişmeler ise kamu kesiminin milli ekonomi içerisindeki payının zamanla büyümesine yol açmıştır (Pehlivan, 2018b: 25). Kamu kesiminin milli ekonomi içerisindeki payı hızlı bir biçimde büyümüş ve bu büyüme eğilimi süreklilik 
Yegen, B. (2019), “Kamu Kesimi Açıklarının Finansmanında Maliye Politikasının Rolü”, Politik Ekonomik Kuram, Cilt 3(2)

kazanmıştır. Şöyle ki 1955'li yıllarda devletin ekonomideki ortalama payı \% 25'lerde seyretmesine karşın, günümüz Avrupa Birliği ülkelerinde \% 45'lere, İskandinav ülkelerinde ise bu oran \% 60'lara kadar ulaşmıştır (Şener, 2010: 29). Yani Büyük Buhran'a kadar klasik iktisadi görüş benimsenmiş olduğu için minimal devlet anlayışı kapsamında kamu kesiminde denklik ilkesi üzerinde hassasiyetle durulmuş, ancak Büyük Buhran'dan sonra benimsenen devlet müdahaleciliği fikriyle birlikte artan kamu harcamalarına bağlı olarak kamu kesimi açıkları yaşanmaya başlanmıştır. Özellikle 1970'li yıllardan sonra daha da yaygınlaşan kamu kesimi açıkları pek çok ülke açısından önemli bir sorun haline gelmiştir (Alkan \& Ümit, 2015: 248).

\section{Kamu Kesimi Açıklarına İlişkin Yaklaşımlar}

Genel olarak ifade etmek gerekirse kamu kesimi açıklarının ekonomik etkileriyle ilgili Keynesyen, Neo-klasik ve Ricardocu olmak üzere üç düşünce okulu bulunmaktadır (Bernheim,1989: 55).

\subsection{Keynesyen yaklaşım}

1929 Büyük Buhranı'na kadar geçerli olan klasik iktisadi görüş devletin sadece üzerine düşen temel görevleri yerine getirmesi gerektiği, devletin ekonominin işleyişine müdahale etmesine gerek kalmaksızın ekonominin kendi dinamikleri ile dengeye geleceği fikrine dayanmaktadır. $\mathrm{Bu}$ yönüyle klasik görüş kamu harcamalarının minimum düzeyde tutulmalarını, bütçe açığı ya da bütçe fazlası hususlarının aksine denk bütçe uygulamalarını öngörmüştür. Ancak klasik görüş 1929 Büyük Buhranı ile artan işsizlik oranlarına bağlı olarak geçerliliğini kaybetmiş, söz konusu görüşün yerini toplam talep yetersizliğini giderme amacı güden ve bu nedenle ekonomiye devlet müdahalesinin elzem olduğu görüşüne dayanan Keynesyen görüşe bırakmıştır.

Keynesyen görüşe göre eksik istihdam problemi talep yetersizliği ile ilişkili olduğu için devlet işsizlikle mücadele edebilmek için kamu harcamalarını artırmaktadır. Artan kamu harcamalarının ise çarpan etkisiyle başta milli gelir olmak üzere istihdam, tüketim ve yatırım düzeyleri üzerinde pozitif etkilere neden olacağı ifade edilmektedir. Ayrıca Keynesyen görüş ekonominin işsizlik ve durgunluk içerisinde olması hâlinde açık finansman politikasının takip edilebileceğini de ifade etmektedir (Gedik, 2008: 249-250).

Geleneksel Keynesyen görüş iki temel nedenden dolayı neo-klasik görüşten ayrılmaktadır. Bunlardan ilkine göre bazı ekonomik kaynakların eksik istihdamda olabilmeleri hususunda, ikincisi çok sayıda kişinin likidite sınırlı olduklarının varsayılması hususunda olmaktadır. Söz 
Yegen, B. (2019), “Kamu Kesimi Açıklarının Finansmanında Maliye Politikasının Rolü”, Politik Ekonomik Kuram, Cilt 3(2)

konusu ikinci varsayım toplam tüketimin harcanabilir gelirdeki değişikliklere karşı çok hassas olduğuna işaret etmektedir (Buscemi \& Yallwe, 2012: 128). Keynesyen bakış açısına göre nüfusun önemli bir kısmı miyop veya likidite kısıtlı olarak düşünülmektedir. Bu bireylerin mevcut harcanabilir gelirden tüketme eğilimi çok yüksek olduğu için geçici bir vergi indirimi toplam talep üzerinde ani ve miktar olarak önemli bir etkiye sahip olmaktadır. Ekonominin eksik istihdamda olması halinde açıklar hem tüketimi hem de milli geliri arttırdığından, tasarruf ve sermaye birikimi olumsuz yönde etkilenmemektedir. Dolayısıyla, uygun şekilde zamanlanmış açıkların yararlı sonuçları bulunmaktadır (Bernheim,1989: 56).

En basit ve en saf Keynesyen modelde, bütçe açığını 1TL arttırmak, milli gelirin marjinal eğilimin tersi yönde artmasına neden olmaktadır. Standart IS-LM analizlerinde, milli gelirdeki bu genişleme para talebini arttırmaktadır. Eğer para arzı sabitse (açıklar tahville finanse edildiğinde) faiz oranları yükselecek ve özel yatırımlar düşecektir (Taş, 1992: 331).

Fakat pek çok geleneksel Keynesyen'e göre bütçe açıkları özel yatırımları dışlamamaktadır. Çünkü bütçe açığına bağlı olarak artış gösteren toplam talep, özel yatırımların kârlılığını artırmakta ve herhangi bir faiz oranında daha yüksek bir yatırım düzeyine yol açmaktadır. Dolayısıyla açıklar, faiz oranlarını artırmalarına rağmen, toplam tasarruf ve yatırımı teşvik edebilmektedir. Bir diğer ifadeyle ekonomide eksik istihdam durumu mevcut olduğunda, aksi yönde bir para politikası uygulanmadığı sürece, önemli nominal bütçe açıkları talebi tam istihdam seviyesine değin artırmaktadır. Talepteki bu artış tüketim ile yatırıma yansımakta ve neticede artan faiz oranına rağmen dışlama etkisi ortaya çıkmamaktadır (Ataç, 2006: 220-221).

\subsection{Neo-klasik yaklaşım}

Kamu kesimi açığının finansmanının makroekonomik etkileri konusundaki bir diğer yaklaşım neo-klasik yaklaşımdır. Standart neo-klasik model üç temel özelliğe sahip olmaktadır. Bunlardan ilkine göre bir ekonomide kişilerin tüketimi piyasalar arası faiz oranlarında borçlanma ve borç vermeye izin verilen, dönemler arası bir optimizasyon probleminin çözümü olarak belirlenmektedir. İkincisinde kişilerin ömürlerinin sınırlı olduğu ve kişilerin belirli bir nesle veya kuşağa aittir oldukları ifade edilmektedir. Üçüncüsünde ise piyasanın tüm dönemlerde genellikle dengede olduğu ifade edilmektedir (Bernheim,1989: 57). Anlaşıldığ1 üzere neo-klasik yaklaşım dâhilinde kişiler tüketim planlarını yaparken yaşam sürelerini dikkate almaktadırlar. Kamu kesimi açığıyla ilgili dönemdeki vergi yükü gelecek nesillere aktarılmaktadır. Tam istihdam durumunda ise artan tüketim, tasarrufun azalmasına neden olacak ve sermaye piyasasını dengeye getirmek için faiz oranları yükselecektir. Bu durumda 
Yegen, B. (2019), “Kamu Kesimi Açıklarının Finansmanında Maliye Politikasının Rolü”, Politik Ekonomik Kuram, Cilt 3(2)

sürekli açıklar özel sermaye birikimini olumsuz şekilde etkileyerek dışlayacaktır (Akder, 1990: $1)$.

Neo-klasiklere göre kamu kesiminde gelir gider dengesi sağlanmalı, kamu kesiminin büyüklüğü sınırlı tutulmalı ve harcamalar ekonomik kararlar üzerinde belirleyici olmayan yansız vergilerle finanse edilmelidir. Çünkü harcamaların finansmanında borçlanma yoluna gidilmesinin ekonominin işleyişini bozacağı düşünülmektedir (Önder, 2014: 154). Şöyle ki kamu kesimi açıklarının finansmanında borçlanmaya başvurulması halinde alınan borçların faiz ve anapara ödemeleri sonraki nesillere genellikle vergi yükü şeklinde yansıyabilmektedir (Gürler, 1998: 21).

Neo-klasik yaklaşım kapsamında ayrıca sürekli ve geçici kamu kesimi açıkları ayrımı yapılmaktadır. Buna göre sürekli olmayan geçici kamu kesimi açıkları ekonomiyi daha az etkilemekte ve kısa dönemde tasarruflar üzerinde olumlu etkiye neden olabilmekte iken sürekli kamu kesimi açıkları, yatırımları düşürmek suretiyle sermaye birikimini olumsuz şekilde etkileyebilmektedir (Eroğlu, 1998: 4).

Sahip olduğu varsayımlar dikkate alındığında neo-klasik yaklaşım tam istihdam varsayımı hususunda Keynesyen yaklaşımdan, sınırlı yaşam süresi hususunda Ricardocu yaklaşımdan ayrılmaktadır (Taş, 1992: 330).

\subsection{Ricardocu eşdeğerlik yaklaşımı}

Ricardocu yaklaşımda ekonomik birimler tüketim ve tasarruf kararlarını verirken yaşam boyu gelirlerini dikkate aldıkları için kamu kesimi açıklarının iç borçlanma ya da vergi ile finanse edilmesinin ekonomi üzerinde aynı etkiye sahip olacağı ifade edilmektedir. Buna göre kamu kesimi açıklarının finansmanında kamu kesiminin ekonomideki genişliği artırılmadan ister vergi ister iç borçlanma yoluna gidilebilmektedir. Ricardocu yaklaşımda rasyonel oldukları varsayılan kişilerin davranışları belirleyici olmaktadır. Bu kapsamda kamu kesimi açığının borçlanma ile finanse edilmesi halinde kişiler borçlanmanın gelecekte anapara ve faiz ödemelerini içeren vergi artışları olarak döneceğini bildikleri için tasarruflarını artırmaktadırlar. Böylece kişiler devlet tarafından borç senetleri ihraç edildiğinde gelecek dönemde karşılaşılacakları borç yükümlülüğünü düşünerek tüketimlerini kısmakta ve tasarruf yapmaktadırlar (Çomaklı vd., 2018: 429). Artan tasarruflara bağlı olarak faiz oranlarında ise herhangi bir artış olmamakta ve dolayısıyla yatırımlar dışlanmamaktadır (Ataç, 2006: 223).

Kamu kesimi açıklarının finansmanında borçlanma ile vergilemenin eşit etkiye sahip olduğu yönündeki düşünceyi ortaya atan iktisatçı David Ricardo olmakla birlikte söz konusu düşünceyi 
Yegen, B. (2019), “Kamu Kesimi Açıklarının Finansmanında Maliye Politikasının Rolü”, Politik Ekonomik Kuram, Cilt 3(2)

sistematik olarak inceleyen kişi Robert J. Barro olmuştur. Ricardocu yaklaşım belirli varsayımlara dayanmaktadır (Gedik, 2008: 246-248).

* Tüketiciler rasyonel ve ileri görüşlü olarak varsayılır.

* Kişilerin kendilerini önemsedikleri kadar gelecek nesilleri de önemsedikleri, bu nedenle kişilerin geçmişe ve geleceğe bağlı olarak sonsuz zaman ufkuna sahip oldukları varsayılır.

* Sermaye piyasalarının mükemmel bir işleyişe sahip oldukları varsayılır.

* Ertelenen vergiler nedeniyle kaynakların nesiller arasında yeniden dağılmadığı varsayilir.

* Vergilerin bozucu etkileri olmadığı varsayılır.

* Mali araç olarak açık finansmanının uygunluğunun maliye politikasını etkilediği varsayilır.

* Kamu harcamaları düzeyinin sabit olduğu ve iktisadi değer oluşturmadığı varsayılır.

\section{Kamu Kesimi Açığı Durumunda Uygulanması Muhtemel Maliye Politikası Araçları}

Devletler tarafından makroekonomik hedeflere ulaşmak için kamu harcamalarının ve kamu gelirlerinin büyüklük ve bileşimlerinde yapılan değişiklikler şeklinde ifade edilebilen maliye politikası, para politikası ile birlikte iktisat politikasını oluşturmakta ve bu nedenle ülke ekonomisi üzerinde son derece önemli bir role sahip olmaktadır (Ataç, 2006: 36). Devletin mali araçlarla genel ekonomiyi yönlendirmesi olarak da ifade edilebilen maliye politikası ile temel iktisat politikası amaçlarına paralel olarak ekonomik istikrarın ve büyümenin sağlanması, tam istihdamla birlikte fiyat istikrarının sağlanması ve gelir dağılımında adalet sağlanması hedeflenmektedir. Diğer bir ifadeyle maliye politikası ile devlet belirli iktisadi ve sosyal çıktıları elde etmek için kamu gelir ve harcamalarını düzenlemektedir (Pehlivan, 2018b: 285). Maliye politikasında kamu gelirleri ve kamu harcamaları olmak üzere iki temel unsur bulunmakta, bu kapsamda kullanılması muhtemel olan maliye politikası araçları vergiler, borçlanmalar ve kamu harcamaları olmakta ve söz konusu araçlar aracılığıyla ekonominin tamamı üzerinde çeşitli etkilere neden olunabilmektedir. Bu kapsamda ekonomik dengeyi olumsuz etkileyen hususlarla mücadele edilebileceği gibi, istihdam konusunda da olumlu gelişmelere neden olunabilmektedir. Ayrıca toplam talep düzeyini de yine maliye politikası araçları ile artırıp azaltmak mümkün olabilmektedir (Akdoğan, 2009: 472-473). Anlaşılacağı üzere maliye politikası temel olarak kamu kesimi bütçesi vasıtasıyla uygulanmakta ve bu yüzden maliye politikasının amaçlarına ulaşmasında kullanabileceği en önemli araçlar bütçe 
Yegen, B. (2019), “Kamu Kesimi Açıklarının Finansmanında Maliye Politikasının Rolü”, Politik Ekonomik Kuram, Cilt 3(2)

açığı veya fazlası olmaktadır (Ataç, 2006: 44). Yani ekonomik dalgalanmalara bağlı olarak tercih edilen maliye politikası benimsenen bütçe anlayışını yansımaktadır. Bu nedenle kamu kesimi bütçeleri zaman zaman açık vermekte ve açık veren bütçeler çeşitli yöntemlerle finanse edilmektedir. Bu kapsamda kamu kesimi açıkları ağırlıklı olarak borçlanma yoluyla finanse edilebileceği gibi vergilerle de finanse edilebilmektedir. Kamu kesimi açıklarının finansman yöntemleri arasında emisyon (para basılması) da bulunmakla birlikte söz konusu yöntem enflasyona yol açması nedeniyle uzun süre sürdürülemediği için genellikle ülkeler tarafından tercih edilmemektedir.

\subsection{Kamu kesimi açıklarının borçlanma yoluyla finanse edilmesi}

Klasik maliye teorisi borçlanmayı olağan finansman yöntemi olarak kabul etmemekte, ancak uzun vadeli yatırımlar için ya da savaş ve benzeri olağanüstü hallerde borçlanma yapılmasını kabul etmektedir. Ancak günümüzde kamu kesimi açıklarında yaşanan artış eğilimine bağlı olarak ülkelerde kamu kesimi açıklarının finansmanında vergilemeye alternatif olarak borçlanma yöntemi tercih edilebilmektedir. $\mathrm{Bu}$ nedenle günümüzde borçlanma, vergi gibi olağan bir gelir türü olarak kabul edilmekte ve kamu kesimi açıklarının finansmanında iç ya da dış borçlanma yapılabilmektedir (Çomaklı vd., 2018: 256).

Ancak yapılan iç ve dış borçlanmaların verimli olarak kullanılmamaları ve alınan borçların faiz ödemeleri ile birlikte ödenmeleri hususunda yaşanan problemler kamu kesimi açıkları ve borç stoklarının artmalarına neden olabilmektedir. Borçlanmanın süreklilik kazanması faiz yükünün artmasına ve bu durum da yeni borçlanmalara ihtiyaç duyulmasına yol açabilmektedir. Yeni borçlanmaların yapılabilmeleri ise yüksek faiz oranlarını gerektirdiği için kamu finansman açığı kısır bir döngü içerisine girebilmektedir (Çukurçayır, 2016: 2-3). Bu durumda yüksek faiz oranları ile yapılan iç borçlanma özel kesimin yatırım için kullanacağı kaynakların azalmasına, dolayısıyla özel kesim yatırımlarının azalmalarına (crowding-out) neden olmaktadır. Ayrıca yüksek faiz oranları üzerinden yapılan ödemeler gelir dağılımı üzerinde de olumsuz etkilere neden olabilmekle birlikte enflasyonist baskılara yol açan tüketim harcamalarının artmalarına ve tasarrufların azalmalarına neden olabilmektedir (Evgin, 1995: 215). Yani kamu kesimi açıklarının finansmanında iç borçlanmaya başvurulması üretim ekonomisi üzerinde negatif etkilere neden olmakta ve uzun vadede sonraki nesillerin vergi yükünü artırabilmektedir. $\mathrm{Bu}$ kapsamda aşırı iç borçlanma ülkeler için tehlikeli bir maliye politikası aracı olabilmektedir (Aktan, 1996: 25). 
Yegen, B. (2019), “Kamu Kesimi Açıklarının Finansmanında Maliye Politikasının Rolü”, Politik Ekonomik Kuram, Cilt 3(2)

Açıkların finansmanında dış borçlar tercih edildiği zaman ülkeye döviz girdisi yapılmaktadır. Dış borçlanma yoluyla sağlanan dövizler yatırımların finansmanda kullanılmadıkları takdirde uzun dönemde ekonomik zarara yol açmaktadırlar. Dış borçlanmanın etkisi genelde enflasyonist yönde olmaktadır. Dış borçlanma ile elde edilen dövizlerin kamu harcamalarının finansmanında kullanılmaları emisyon artışına yol açmakta ve çoğaltan mekanizması sayesinde toplam talebi genişletmektedir (Duran, 1996: 450). Nitekim Sargent ve Wallace (1981) "Hoş Olmayan Monetarist Aritmetik" isimli düşünce kapsamında kamu kesimi açıklarının finansmanı hususunda borçlanmanın tercih edilmesinin uzun dönemde borçların parasal finansmanından daha büyük enflasyonist sonuçlara yol açacağını ifade etmişlerdir. Yani borçlanma politikasına bağlı olarak devletin faiz yükü ile karşılaşacağı ve nihayetinde enflasyondan kaçamayacağı ifade edilmektedir (Altıntaş vd., 2008: 188).

Anlaşıldığg üzere kamu kesimi açıklarının finansmanında borçlanma olgusu zamanla ülkeler tarafından olağan bir finansman aracı gibi benimsenmiştir. Ancak söz konusu aracın tercih edilmesi ülkelerde ciddi miktarda büyük borç yükleri, enflasyon, borç krizleri ve yüksek faiz oranları gibi olumsuz ekonomik unsurlara neden olabilmektedir.

\subsection{Kamu kesimi açıklarının vergiler yoluyla finanse edilmesi}

Kamu kesimi açığının finansmanında vergiler önemli bir yere sahip olmaktadır. Şöyle ki kamu kesimi açığının finansmanında vergiler ile borçlanma karşılaştırıldığında borçlanmanın bir takım dezavantajlara sahip olduğu ifade edilmektedir. Buna göre borçlanmanın vergilere göre geçici bir çözüm sunduğu, borçlanmanın taraflar arasındaki rızaya bağlı olduğu, borçlanmanın faiz maliyeti olduğu, borçlanmanın vergilerin aksine vergi yükünü çoğu zaman gelecek nesillere aktardığı ifade edilmektedir (Çataloluk, 2009: 244). Bu nedenlerden dolayı kamu kesimi açıklarının finansmanı konusunda en sağlıklı ve ekonomiye en az zarar veren yöntem vergi gelirlerinin artırılması olmaktadır. Vergiler yalnızca toplam talebin azaltılması suretiyle tüketimin önüne geçerek ekonomide borçlanma ve emisyona kıyasla daha olumlu sonuçlara neden olmaktadırlar. Buna karşın vergileme ile ilgili tüm olanakların değerlendirilmiş olmalarından ve vatandaşların vergilerle ilgili yapılan gelişmelere (vergi artışları ya da yeni vergi konulması) gösterecekleri tepkilerden dolayı kamu kesimi açıklarının finansmanında vergiler kullanılmayabilir (Parlaktuna \& Şimşek, 2007: 45). Öte yandan vergi sistemlerinin devresel dalgalanmalar karşısında kolayca uygulanma olanağı sağlayacak şekilde esnek olması gerekmektedir. Bu kapsamda vergi mevzuatında yapılacak yasal düzenlemeler aktif esnekliği, vergi sisteminin içerisinde bulunan otomatik stabilizatörler ise pasif esnekliği ifade etmektedir. Hem aktif hem de pasif esnekliğe sahip olması gereken vergi sistemlerinin ekonomik genişleme 
Yegen, B. (2019), “Kamu Kesimi Açıklarının Finansmanında Maliye Politikasının Rolü”, Politik Ekonomik Kuram, Cilt 3(2)

dönemlerinde enflasyonla mücadele hususunda, daralma dönemlerinde durgunlukla mücadele hususunda vergilerin kolayca artırılabilecek ya da azaltılabilecek karma bir yapıya sahip olmaları gerekmektedir (Pehlivan, 2018b: 296-297).

Özetle kamu kesimi açıklarının vergilerle finansmanı borçlanmaya kıyasla daha olumlu ekonomik sonuçlara neden olmaktadır. Ancak günümüzde devletler tarafından kamu kesimi açıklarının finansmanında vergilerden ziyade borçlanmanın tercih edildiği bilinmektedir. Çünkü vergilerin bu konudaki hareket alanı oldukça kısıtlı olmaktadır. Şöyle ki mevcut açığı kapatmak için yeni vergilerin konulması ya da vergi oranlarının artırılması halk tarafından iyi karşılanmayabilmektedir. Çünkü ülkemizde vergiler gelir, tüketim ve servet üzerinden alınmakta olduğu için kişilerden bu hususlar üzerinden daha fazla vergi alınmak istenmesi, kişilerin varlıklarında azalmalara yol açacağı için kişiler tarafından olumlu karşılanmamakta ve tepkilere neden olmaktadır. Ayrıca uygulanan vergi oranlarını artırmak da teorik olarak bir noktaya kadar mümkün olabilmektedir. Yani Laffer eğrisinde de bahsedildiği üzere vergi gelirleri ile vergi oranları arasındaki ilişki optimum noktasına doğru orantılı şekilde gerçekleşmekteyken, optimum noktasının aşılmasıyla birlikte söz konusu ilişki ters orantılı şekilde gerçekleşmektedir. Bir diğer ifadeyle vergi oranlarını belirli bir noktaya kadar artırmak vergi gelirlerini artırmakta, bu noktadan sonra artırılan vergi oranları vergi gelirlerini düşürmektedir. Bu nedenlerden ötürü kamu kesimi açıklarının finansmanında vergi gelirlerini artıracak uygulamalara yer verilmesi önemli bir yöntem olarak kabul edilmekle birlikte söz konusu yöntemin uygulanabilirliği yukarıda ifade edilen kısıtlara bağlı olmaktadır.

\section{Maliye Politikaları Kapsamında Kamu Kesimi Bütçe Anlayışı}

Kamu kesimi bütçe anlayışı durgunluk ve enflasyon gibi konjonktürel dalgalanma dönemlerinde ortaya çıkan olumsuz ekonomik hususlarla mücadele etmek için uygulanan maliye politikası türüne göre farklılık göstermektedir. Bu bağlamda bütçe açığı ya da bütçe fazlası anlayışı tercih edilebilmektedir.

\subsection{Genişletici maliye politikası kapsamında bütçe açı̆̆ı anlayışı}

Toplam talebin yetersiz olduğu, yani toplam arz karşısında toplam talebin eksik kalması durumunda genel ekonomik denge mevcut toplam arz-toplam talep dengesizliğine bağlı olarak bozulmakta ve ekonomide durgunluk süreci ortaya çıkabilmektedir. Durgunluk sürecinde toplam talep eksikliğine bağlı olarak üretim düzeyi ekonominin üretim kapasitesinin tam kapasitenin altında kullanılmasını sağladığı için milli gelir eksik istihdam seviyesinde gerçekleşmekte, işsizlik oranı artmakta ve faktör ile mal fiyatlarında genel bir azalma trendi 
Yegen, B. (2019), “Kamu Kesimi Açıklarının Finansmanında Maliye Politikasının Rolü”, Politik Ekonomik Kuram, Cilt 3(2)

yaşanmaktadır. Toplam arz ile toplam talep arasında toplam arzın lehine olan bu dengesizliği gidermek için ya toplam arz düşürülmeli ya da toplam talep artırılmalıdır. Ancak toplam arzı düşürmek ekonominin üretim kapasitesinin tam olarak kullanılmamasına neden olacağı için geçerli bir çözüm olmamaktadır. Bu nedenle durgunluk mücadele hususunda toplam arz ile toplam talep arasındaki fark, toplam talebin artırılması suretiyle dengelenmektedir (Ataç, 2006: 185-190).

Durgunluk döneminde takip edilen maliye politikasına genişletici ya da telafi edici maliye politikası denilmektedir. Söz konusu durgunluk döneminde mevcut talep açığını gidermek için kamu harcamaları artırılarak halkın tüketim eğiliminin artırılması, vergi gelirleri azaltılarak halkın kullanılabilir gelirinin artırılması hedeflenmektedir. Böylece kamu harcamalarının artırılması yoluyla toplam talep doğrudan etkilenirken, vergilerin azaltılmaları yoluyla toplam talep dolaylı olarak etkilenmektedir. Anlaşıldığı üzere her iki yöntemde de temel amaç toplam talebin artırılması yoluyla ekonominin tam istihdam denge seviyesine gelmesini sağlayacak açık bütçe anlayışı benimsenmektedir. Bahsedilen şekillerde artırılan toplam talep ise üretim, istihdam ve milli gelir artışına yol açmaktadır. Şüphesiz kamu harcamalarının artırılma sınırı kamu harcamalarının çarpan etkisi de dikkate alınmak suretiyle iyi tespit edilmiş olmalıdır. Çünkü deflasyonist açığı kapatmaya yönelik yapılan fazla kamu harcamalarının tam istihdam denge seviyesinin üzerine çıkması halinde bu kez ekonomi enflasyon olgusuyla karşı karşıya kalabilmektedir (Pehlivan, 2018b: 286-288).

Özetle toplam talep yetersizliğine bağlı olarak ekonomik durgunluğun yaşandığı dönemlerde içinde bulunulan olumsuz durumdan kurtulmak için bütçe açığına yol açması kuvvetle muhtemel olan genişletici maliye politikası takip edilebilmektedir. Söz konusu politika dâhilinde ise kamu harcamalarını artırmak ve/veya kamu gelirlerini azaltmak şeklinde alternatif seçenekler mevcut olmaktadır. Ancak enflasyona neden olabileceği için uygulanacak politika dâhilinde toplam talep düzeyinin olması gereken düzeyden (tam istihdam denge düzeyi) daha fazla artırılmamasına özen gösterilmelidir.

\subsection{Daraltıcı maliye politikasının etkileri}

Ekonominin tam istihdam durumundan uzak olduğu, toplam talebin toplam arzı aştığı hâllerde enflasyonist açık ortaya çıkmaktadır. Böyle bir durumla karşı karşıya kalındığı takdirde bütçe politikası üç farklı şekilde uygulanabilmektedir (Çomaklı vd., 2018: 396):

* Vergi sistemi değiştirilmeksizin kamu harcamaları azaltılabilir, 
Yegen, B. (2019), “Kamu Kesimi Açıklarının Finansmanında Maliye Politikasının Rolü”, Politik Ekonomik Kuram, Cilt 3(2)

* Kamu harcamaları azaltılırken aynı zamanda kamu gelirleri içerisinde en büyük paya sahip unsur olan vergileri artırılabilir,

* Kamu harcama düzeyi değiş̧irilmeksizin vergi gelirleri artırılabilir.

Kamu gelirlerine dokunmaksızın kendisi talep niteliğinde olan veya talebe sebep olan işlemlerden meydana gelen kamu harcamalarının azaltılması halinde toplam harcamalarda oluşacak azalma kamu harcamaları çarpanına bağlı olarak ekonomide daha fazla daraltıcı etkiye sebep olmaktadır. Tersi durumda kamu harcamalarına dokunmaksızın kamu gelirleri artırıldığında (özellikle başta gider vergilerine ve gelir vergilerine ilişkin vergi gelirlerini artırmak suretiyle) kişilerin kullanılabilir gelirlerinde, bu yolla özel tüketim ve yatırım harcamalarında azalma ortaya çıkmaktadır. Böylece ekonomide toplam arza kıyasla fazla olan toplam talep miktarını aşağı çekmek mümkün olabilmektedir (Ataç, 2006: 165-171).

Yukarı da sayılan bütçe uygulamaları ile toplam talep tam istihdam denge düzeyine getirilmeye çalışılmaktır. Fakat söz konusu uygulamalar takip edilirken üzerinde önemle durulması gereken husus toplam talebin tam istihdam denge düzeyine değin indirilmesi olup, toplam talebin denge düzeyinin altına indirilmesinden kaçınılması gerektiğidir. Çünkü böyle bir durumun gerçekleşmesi halinde istihdam, üretim ve özel yatırımların düşmesine bağlı olarak ekonomi durgunluğa sürüklenebilmektedir (Pehlivan, 2018b: 295). Bu nedenle enflasyonist açığın olduğu bir durumda daraltıcı maliye politikası takip edildiği takdirde söz konusu politikada kullanılan araçların ekonomik etkilerinin ve uygulanacak politikanın sonucunda ortaya çıkması muhtemel sonuçların önceden iyi bir şekilde bilinmesi gerekmektedir.

Ayrıca 1970'li yıllarla birlikte görülmeye başlayan enflasyon ve işsizlik olgularının birlikte ortaya çıtıkları stagflasyon hususunda daraltıcı maliye politikası anlayışı toplam talebi azaltmak suretiyle enflasyonla mücadele konusunda geçerli bir çözüm olmasına karşın, işsizlik oranının azaltılması için genişletici maliye politikasının takip edilmesi gerekmektedir. $\mathrm{Bu}$ nedenle stagflasyonla mücadelede daraltıcı ve genişletici maliye politikalarının amaçları çatışmaktadır. Stagflasyon ikilemine karşı tam bir çözüm önerisi bulunmamakla birlikte gelirler politikası, vergi temelli gelir politikaları, indeksleme ve üretim teşvikleri politikası gibi çeşitli politika önerileri bulunmaktadır (Ataç, 2006: 201-215).

\section{Sonuç}

Günümüzde benimsenen müdahaleci devlet anlayışı kapsamında devletin artan görev ve sorumlukları daha fazla kamu harcaması yapılmasına yol açmakta ve doğal olarak bütçe açıkları ortaya çıkmaktadır. Bütçe açıklarının finansmanı hususunda Keynesyen yaklaşım, Neo-klasik 
Yegen, B. (2019), “Kamu Kesimi Açıklarının Finansmanında Maliye Politikasının Rolü”, Politik Ekonomik Kuram, Cilt 3(2)

yaklaşım ve Ricardocu yaklaşım olmak üzere üç farklı yaklaşım bulunmaktadır. Keynesyen anlayış devletin temel görevlerinin yanı sıra ekonomik ve sosyal hayata müdahale etmesi gerektiği düşüncesini ileri sürmekle birlikte ekonominin genel denkliğine önem vermekte ve bu nedenle devlet bütçesinin açık vermesi Keynesyen anlayışa göre olağan karşılanmaktadır. Neoklasik anlayışa göre ise bütçe açıkları gelecek nesillere vergi yükü şeklinde yansıyacağı için kamu kesiminde gelir gider dengesinin sağlanması gerektiği ifade edilmektedir. Ricardocu yaklaşımda ise bütçe açıklarının borçlanma ya da vergi ile finanse edilmesinin ekonomi üzerinde aynı etkiye neden olacağı belirtilmektedir.

Bütçe açıklarının finansmanında ise vergiler, borçlanma ve emisyon olmak üzere üç farklı yöntem bulunmaktadır. Söz konusu yöntemler içerisinde en sağlıklı yöntem vergiler olmasına karşın vergilerin uygulanmaları konusunda Laffer eğrisinde ifade edildiği üzere bazı kısıtlar bulunmaktadır. Emisyon yöntemi ile bütçe açıklarının finanse edilmesi durumunda ise söz konusu işlem enflasyona yol açabilmektedir. $\mathrm{Bu}$ nedenle günümüzde pek çok devlet bütçe açıklarının finansmanı konusunda daha çok iç ve/veya dış borçlanmayı kullanmaktadır. Ancak borçlanma yöntemi de kısır bir borç döngüsü, borç stoklarının artması ve özel kesim yatırımlarının dışlanmaları (crowding-out) gibi bir takım sorunlara yol açabilmektedir. $\mathrm{Bu}$ nedenle ciddi ekonomik sorunlarla karşı karşıya kalınmaması adına borç yönetimi hususunda ülkelerin dikkatli şekilde hareket etmeleri gerekmektedir.

Ayrıca durgunluk ve enflasyon gibi çeşitli ekonomik sorunlarla karşı karşıya kalındığında farklı maliye politikaları ve farklı bütçe anlayışları benimsenmektedir. Şöyle ki durgunluk döneminde genişletici maliye politikasının takip edilmesi halinde kamu harcamaları artırılmakta ve/veya vergi gelirleri azaltılmaktadır. Böylece toplam talebi artırarak ekonominin tam istihdam denge seviyesine gelmesini sağlayacak açık bütçe anlayışı benimsenmektedir. Enflasyonist dönemde ise daraltıcı maliye politikasının takip edilmesi halinde kamu harcamaları azaltılmakta ve/veya vergi gelirleri artırılabilmektedir. Daraltıcı maliye politikası ile toplam talebin azaltılarak tam istihdam denge seviyesine gelmesini sağlayacak bütçe fazlası anlayışı benimsenmektedir. Ancak hangi bütçe anlayışı benimsenirse benimsensin uygulanan maliye politikalarının ve politika araçlarının tam istihdam denge seviyesinin dikkate alınarak uygulanmaları gerekmektedir. 
Yegen, B. (2019), “Kamu Kesimi Açıklarının Finansmanında Maliye Politikasının Rolü”, Politik Ekonomik Kuram, Cilt 3(2)

\section{Kaynakça}

Adak, M., 2010. Kamu Açıkları ve Ekonomik Büyüme: Türkiye Örneği. Maliye Dergisi, 159, 233-243.

Akder, T.. 1990. 1990 Yılında Kamu Açılkları ve Finansmanı. Ankara: T.C. Merkez Bankası Araştırma Planlama ve Eğitim Genel Müdürlüğü, Tartışma Tebliğ No 9008.

Akdoğan, A., 2009. Kamu Maliyesi. 13. Bask1, Ankara: Gazi Kitabevi.

Aktan, C. C., 1996. Ekonomik Anayasa. Ankara: TiSK Yayın No 162.

Alkan, H. I. \& Ümit, A. Ö., 2015. Türkiye'de Kamu Açıları: 1980-2012 Dönem Analizi. Türkiye Sosyal Araştırmalar Dergisi, 1(1), 247-274.

Altıntaş, H., Çetintaş, H. \& Taban, S., 2008. Türkiye'de Bütçe Açı̆̆ı, Parasal Büyüme ve Enflasyon Arasındaki İlişkinin Ekonometrik Analizi: 1992-2006. Anadolu Üniversitesi Sosyal Bilimler Dergisi, 8(2), 185-208.

Ataç, B., 2006. Maliye Politikası. Eskişehir: Etam A.Ş. Matbaa Tesisleri.

Bernheim, B.D., 1989. A Neoclassical Perspective on Budget Deficits. Joumal of Economic Perspectives, 3(2), 55-72.

Buscemi, A. \& Yallwe, A. H., 2012. Fiscal Deficit, National Saving and Sustainability of Economic Growth in Emerging Economies: A Dynamic GMM Panel Data Approach. International Journal of Economics and Financial Issues, 2(2), 126-140.

Çataloluk, C., 2009. Kamu Borçlanması, Gerçekleşme Biçimi ve Makro Ekonomik Etkileri (Teorik Bir Yaklaşım, Türkiye Örneği). Balıkesir Üniversitesi Sosyal Bilimler Enstitüsü Dergisi, Cilt 12(21), 240-258.

Çomakl1, Ş. E., Turan, D. \& Doğruyol, C., 2018. Kamu Maliyesi. 5. Baskı, Ankara: Savaş Yayınevi.

Çukurçayır, S., 2016. Türkiye'de Bütçe Açıkları ve Dış Borç Sorunu Üzerine Bir İnceleme. Maliye Araştırmaları Dergisi, 2(2), 1-12.

Duran, M., 1996. Kamu Finansman Açıklarının Optimal Finansmanı. Kamu Kesimi Finansman Açıkları, X. Maliye Sempozyumu, Mayıs 1994, Antalya, İstanbul Üniversitesi Basımevi, No: 554, İstanbul.

Eroğlu, A. S., 1998. Bütçe Açı̆̆ı-Cari İşlemler Açı̆̆ı İlişkisi: Türkiye Üzerine Bir Deneme. Ankara: DPT Uzmanlık Tezi, Yayın No: DPT 2489.

Evgin, T., 1995. 90'lı Yıllarda İç Borçlarımızın Ekonomik Açıdan Değerlendirilmesi. Ankara Üniversitesi Siyasal Bilgiler Fakültesi Dergisi, 50(1), 209-220.

Gedik, M., 2008. Kamu Açıklarına İlişkin Maliye Politikası Uyarlamaları ve İktisadi Etkileri. Ç.Ü. Sosyal Bilimler Enstitüsü Dergisi, 17(1), 245-268.

Gürler, A. S., 1998. Devlet İç Borçlanma Yöntemleri OECD ve Türkiye Uygulamaları. Ankara: DPT Uzmanlık Tezi, Yayın No: DPT 2488.

Kirmanoğlu, H., 2011. Kamu Ekonomisi Analizi. 3. Bask1, İstanbul: Beta Yayınc1lık.

Önder, İ., 2014. Bütçe Açı̆̆ı Sorunsalı. Ed. Beyhan Ataç, Maliye Politikası I (150-170), Eskişehir: Anadolu Üniversitesi Açık Öğretim Fakültesi Yayını, No: 2560. 
Yegen, B. (2019), “Kamu Kesimi Açıklarının Finansmanında Maliye Politikasının Rolü”, Politik Ekonomik Kuram, Cilt 3(2)

Parlaktuna, İ. \& Şimşek, S., 2007. Bütçe Finansman Kaynaklarının Belirlenmesi ve Ekonomi Üzerindeki Etkileri: Türkiye Uygulaması (1989-2005). Eskişehir Osmangazi Üniversitesi Sosyal Bilimler Dergisi, 8(2), 43-67.

Pehlivan, O., 2018a. Devlet Bütçesi. 6. Bask1, Trabzon: Celepler Matbaacılık.

Pehlivan, O., 2018b. Kaти Maliyesi. Trabzon: Celepler Matbaacılık.

Sargent, T. J. \& Wallace, N. 1981. Some Unpleasant Monetarist Arithmetic. Federal Reserve Bank of Minneapolis Quarterly Review, 5(3), 1-17.

Şener, O., 2010. Teori ve Uygulamada Kamu Ekonomisi. 11. Baskı, İstanbul: Beta Yayınc1lık.

Taş, R., 1992. Theoretical and Empirical Aspects of Budget Deficits. Ankara Üniversitesi SBF Dergisi, 47(3), 327-341. 